\title{
Effects of Three Organic Amendments on Polycyclic Aromatic Hydrocarbon Degradation from Crude Oil Polluted Artisanal Refining Site
}

\author{
S. I. Douglas ${ }^{1 *}$, C. J. Ugboma and O. J. Onwukwe \\ Department of Microbiology, Faculty of Science, Rivers State University, PMB 5080, \\ Nkpolu-Oroworukwo, Port Harcourt, Rivers State, Nigeria \\ *Corresponding author
}

\begin{tabular}{|c|}
\hline Keywords \\
\hline $\begin{array}{l}\text { Biostimulatory, } \\
\text { Amendments, } \\
\text { Bioremediation, } \\
\text { Polycyclic aromatic } \\
\text { hydrocarbon, } \\
\text { Biodegradation }\end{array}$ \\
\hline Article Info \\
\hline $\begin{array}{l}\text { Accepted: } \\
07 \text { November } 2020 \\
\text { Available Online: } \\
10 \text { December } 2020\end{array}$ \\
\hline
\end{tabular}

\section{A B S T R A C T}

Bioremediation of hydrocarbon polluted soil occurs through the utilization of these hydrocarbons as a source of carbon and energy by microorganisms present in the polluted soil, so as to restore and reclaim an environment damaged by these pollutants. The activities of these microorganisms can be enhanced for faster biodegradation by the addition of organic and inorganic nutrients via biostimulation. This research involved laboratory scale bioremediation experiment conducted to compare the effectiveness of three different organic amendments, on the biodegradation of polycyclic aromatic hydrocarbon (PAH) monitored for 28days. The application of agricultural waste materials as a way of biostimulating the indigenous microbiota for the bioremediation of crude oil and hydrocarbon polluted soil was evaluated. The aim of this research is to evaluate the effect of three different organic amendments (fishpond effluent/waste, spent mushroom substrate and compost soil) on polycyclic aromatic hydrocarbon degradation in other to determine the amendment that have the highest biodegradation potential (efficiency). Oil polluted soil samples were collected from an abandoned artisanal crude oil refining site in Ngia-Ama Kiri in Degema Local Government Area, of Rivers State. The organic amendments used for biostimulation were: Fishpond effluent/ waste (FPE), Spent mushroom substrate (SMS) and Compost soil (CS). Bioremediation process was monitored in 4 experimental setups presented as: 1- Control (Natural attenuation), 2- FPE, 3- SMS and 4- CS for 28 days. Ten percent (10\%) each of the organic amendments were added to $900 \mathrm{~g}$ of polluted soil sample in a microcosm experiment while the control had $1000 \mathrm{~g}$ of polluted soil with no amendment. Samples were taken from each experimental setup and subjected to both microbiological and physiochemical evaluations using standard methods at days 0,14 and 28 . Spread plate method was used to isolate and enumerate Total heterotrophic bacteria (THB) and Hydrocarbon utilizing bacteria. Gas chromatography-flame ionization detector (GC-FID) was used to detect the changes in PAH concentrations of the experimental setups over time. Results obtained were subjected to ANOVA to check for significant difference. Total heterotrophic bacterial counts ranged from $1.3 \mathrm{x}$ $10^{5} \mathrm{Cfu} / \mathrm{g}-2.3 \times 10^{6} \mathrm{Cfu} / \mathrm{g}$ and Hydrocarbon utilizing bacterial counts ranged from $1.0 \times 10^{5} \mathrm{Cfu} / \mathrm{g}-$ $1.32 \times 10^{6} \mathrm{Cfu} / \mathrm{g}$. Amendment with FPE had the most significant bioremediation effect with biodegradation efficiency of $87.4 \%$ and a half-life of 9.3 days as when compared to the other amendments. Statistics and biodegradation kinetics at p-value $<0.05$ showed that, there is a significant difference in the nature and duration of the amendments (biostimulants) applied. Results of this investigation revealed that the different organic wastes used as biostimulating agents had significant biostimulatory effects on PAH degradation as compared to the unamended (control) setup. However, fishpond waste gave the highest biodegradation potential and the least half-life, followed by the spent mushroom substrate. While the least biodegradation potential and highest halflife was observed in the compost setup. Therefore, the use of fish pond effluent may be recommended for use in the bioremediation of polycyclic aromatic hydrocarbon polluted soil. 


\section{Introduction}

The Niger Delta is a rich ecosystem located in the southern part of Nigeria; it covers an area of approximately $70,000 \mathrm{~km}^{2}$. Apart from being known as Africa's largest wetland, it is also considered as one of the most important wetland and marine ecosystems in the world (Denedo et al., 2017). The rich ecosystem of the Niger Delta includes mangrove forests, swamps, coastal ridges, and forests that provide a wide biodiversity which supports large array of flora and fauna as well as high population density of people (Obi, 2010; UNEP, 2011). With the discovery and refining of Crude oil in this region, many man-made and operational system failures during the production process of oil and gas and other "third party interference such as sabotage, stealing of equipment or leaks caused by robbers drilling into pipelines or opening up wellheads to steal oil" has seriously impaired the capacity of the Niger Delta environment to sustain farming, hunting and fishing which are the traditional economic mainstay of the region (SPDC, 2011). Presently, with the upsurge in the area of a lot of artisanry or illegal crude oil refining activities, it is estimated that between 200,000 and 300, 000 barrels of crude oil is taken away daily due to thefts, of which about $75 \%$ are sold offshore and the remaining $25 \%$ refined illegally (Obeneade and Amangabara, 2014; Douglas, 2018; Douglas and Cornelius, 2019).

Locally fabricated fractional distillation column is built from materials including metal drums and pipes welded together, in which the crude oil is cooked locally, then resultant fumes are collected in metal tanks, cooled into products such as diesel, kerosene, premium motor spirit(fuel) and large quantities of waste also produced ( Douglas, 2018). These products are sold and used for local consumption.
Polycyclic aromatic hydrocarbons (also known as polyaromatic hydrocarbons or polynuclear aromatic hydrocarbons (PAHs) (ATSDR, 2011) are made up of multiple aromatic rings (organic rings with delocalized electrons). They are uncharged, non-polar molecules found in coal and in tar deposits and are found everywhere in the universe (Hoover, 2014). There are about 30 parent PAHs in crude oil of which 16 have been identified as important pollutants as a result of their high mutagenic, carcinogenic and teratogenic nature by the United State Environmental Protection Agency (US EPA), World Health Organization (WHO) and European Union (UN) (Chikere et al., 2018). Degradation of these pollutants is necessary to health of living things, sustainable development and safety in the environment (Mrozik and Protrowska-Seget, 2010). There are 3 mechanical principles of PAHs remediation, they are: physical, chemical and biological methods (Tomei and Daugulis, 2013). Although physical and chemical methods are preferred to biological method when urgency arises, but these methods are expensive with much energy required and addition of synthetic chemicals that may cause more environmental problems (Mrozik and Protrowska-Seget, 2010). As a result of these, the use of biological processes to remediate is adopted as it is cost effective with less efforts (Montagnolli et al., 2015), does not use harmful chemicals (Shama, 2012), eco-friendly and sustainable (Dell'Anno et al., 2015).

Bioremediation achieves its purpose via biodegradation as it is known to be any process that utilizes microorganisms or their enzymes and metabolic activities to restore an environment damaged by contaminants to a fit-for-purpose state (Adams et al., 2014). Biostimulation involves the addition of nutrients or substrates to a polluted soil sample so as to enhance the activities of 
indigenous microbes. As microorganisms are ubiquitous in nature, it is evident that pollutant degraders will be naturally present in polluted sites with their numbers and metabolic activities increasing or decreasing in response to pollutant concentration; therefore, the use of agro-industrial wastes with appropriate nutrient composition especially nitrogen, phosphorus and potassium, will help solve the problem of nutrient limitation in most polluted sites (Wang et al., 2012b). Organic amendments are known to improve soil structure and fertility by adding essential nutrients and enhance microbial community of soil (Oldare, 2008). Different organic and inorganic wastes have been assessed as amendments to improve some physical, chemical and biological properties of degraded soils (Santos, 2014). According to HamoudiBelarbi et al., (2017), both bioaugmentation and biostimulation are effective in removing pollutant such as polycyclic aromatic hydrocarbons (PAHs) from heavily polluted sample compared to non-amended process (natural attenuation). Biostimulants with promising results, like carob kibbles, sugarcane bagasse, sugarcane molasses, wheat straw, banana skin, yam peel, saw dust, spent brewing grain, rice husk, and coconut shell have been used earlier( MolinaBarahona et al., 2004). Bacteria display many characteristics making it to be the most capable organism for bioremediation. They can survive anaerobic and harsh environments such as acid mines, heavy metal and radioactive dumps; their adaptive physiological and degradative competence makes them more flexible than any other group of organisms (Chikere et al., 2018). Also, they undergo genetic recombination more than any other microorganism, hence producing needed biomass, biosurfactants, exopolysaccharides, enzymes and catabolic genes to degrade available pollutants (VanHamme, 2003). According to Sayara et al.,
(2009) the utilization of naturally occurring microorganisms instead of augmenting the resident microbes has many advantages. They established that since natural populations have grown over the years, they have adapted to the environment, making their growth and survival easy. Also, they stated that the ability to utilize hydrocarbon is distributed within different microbial population.

The justification for the use of this bioremediation option is that whenever there is oil pollution, carbon concentration in the area increases while other nutrients becomes limiting, affecting hydrocarbon metabolism. Therefore, the addition of organic amendments to the polluted soil, leads to increase in the utilization of the hydrocarbon, increase in microbial biomass, dilute the contaminant and alter the chemical forms so that its toxicity is reduced through a range of exposure pathways (Santos, 2014). Many organic amendments such as compost, poultry waste, cow dung, goat manure and inorganic fertilizer (NPK) has been used in bioremediation of polluted soil in the Niger Delta but fish pond waste is less reported. The aim of this study is to evaluate the effectiveness of three different organic amendments in the biodegradation of PAHs against natural attenuation technique.

\section{Materials and Methods}

\section{Site description and sample collection}

The soil samples used for this research were collected from Ngia-Ama Kiri $\left(4.7947^{\circ} \mathrm{N}\right.$, $6.6831^{\circ} \mathrm{E}$ ) in Degema Local Government Area of Rivers State, an abandoned artisanal crude oil refining site. This island has been polluted for a while prior to sampling, it was a very active artisanal crude oil refining site before an explosion occurred at the site which resulted in a major pollution and abandonment of the Island by the boys. The 
effects of crude oil pollution on the environment are very detrimental and require immediate attention and action. Illegal refining of crude oil in this Island has resulted in the spillage of incompletely refined crude oil and its byproducts which are released indiscriminately into free land space and surrounding water bodies leading to loss of farmland, aquatic and terrestrial lives. The polluted soil samples were collected from four different points bulked together to make a composite soil sample. The soil samples were collected with sterile hand trowel at 0-30 cm depth, put in a sterile polythene bag and transported to the laboratory immediately.

\section{Sample preparation}

The polluted soil sample collected was processed by removing all foreign matters (removing things like stones, sticks). Fifty grams each was removed to be used for baseline physicochemical and microbiological studies. The remaining polluted soil sample was removed of all non- soil particles and kept in a clean bag at ambient temperature to be used later. The amendments used (spent mushroom substrate, fish pond effluent and composite soil) were filtered using a twomillimeter $(2 \mathrm{~mm})$ pore size sieve, the fish pond effluent was dried in the sun for three (3) days while the others were air dried in the laboratory.

\section{Baseline studies}

The baseline physicochemical and microbiological analysis of the soil sample and all three amendments used were done respectively. The polluted soil sample was analyzed to check for total heterotrophic bacteria and hydrocarbon utilizing bacteria, quantify polycyclic aromatic hydrocarbon content (PAH), phosphate, nitrate, $\mathrm{pH}$, temperature and biochemical oxygen demand (only in the fish pond effluent).

\section{Physicochemical analyses}

Total organic carbon (TOC) was determined according to (Avramidis et al., 2016). Determination of polycyclic aromatic hydrocarbons (PAHs) was analyzed according to (Rasdy et al., 2012). The GC-FID analysis was carried out on baseline, day 0, 14 and 28; phosphate was ascertained according to (Singh et al., 1999). Soil pH was carried out by adding $10 \mathrm{~g}$ of each sample into a $100 \mathrm{ml}$ of clean beakers. Deionized water $(20 \mathrm{ml})$ was added and the suspension was thoroughly stirred with glass rod for 30 minutes to obtain homogenous mixture, after which calibrated $\mathrm{pH}$ meter ( $\mathrm{pH}$ tester 20) was dipped into the beaker containing the suspension and the $\mathrm{pH}$ value was recorded after a steady reading. Average $\mathrm{pH}$ value was taken from triplicate readings. The slurry was then filtered. Nitrate was determined according to (Igwo-Ezikpe et al., 2010) and potassium was gotten using (Somawanshi et al., 1994) method.

\section{Bioremediation experimental set-up}

The polluted soil sample was weighed and set up in duplicate making it a total of 8 setups. One thousand grams $(1000 \mathrm{~g})$ each of the soil was placed into 2 sterile pots, this was labeled as the control. Then into each of the pots marked for the 3 amendments (FPE, SMS and CS), 900g of polluted soil each was placed in all the pots and $100 \mathrm{~g}$ of each amendment was added into the appropriate pot and mixed thoroughly. This is as shown in Table 1. Twenty millimeters $(20 \mathrm{ml})$ of sterile distilled water was added into each of the setups and mixed thoroughly using 70\% ethanol sanitized hand trowel, for adequate aeration and to maintain average moisture level; this was done at 3 days interval throughout the 28days monitoring period (Chikere et al., 2018). The experimental setups (the pots) were kept in a greenhouse at ambient temperature. 


\section{Microbiological Analysis}

\section{Isolation and enumeration of total heterotrophic bacteria and hydrocarbon utilizing bacteria}

One gram (1g) of soil sample from each treatment option was suspended into $9.0 \mathrm{ml}$ of sterile normal saline, using 10 -fold serial dilution technique; this was diluted to $10^{-4}$ dilution. Thereafter, $0.1 \mathrm{ml}$ of $10^{-3}$ and $10^{-4}$ dilutions were spread on Nutrient agar plates in triplicate. The plates were incubated at $37^{\circ} \mathrm{C}$ for $24 \mathrm{~h}$ (Douglas and Cornelius, 2019). Colonies that developed after incubation were counted, mean values calculated and colony forming unit per gram also calculated.

Hydrocarbon utilizing bacteria (HUB) were isolated and quantified using mineral salt agar composition of (Mills et al., 1978) modified by (Okpokwasili and Okorie, 1988). The medium was supplemented with $0.05 \mathrm{~g} / \mathrm{ml}$ of nystatin (antifungal powder) and 1\% Bonny light crude oil (Stanley et al., 2015). An aliquot $0.1 \mathrm{ml}$ of $10^{-3}$ and $10^{-4}$ dilutions were plated out in triplicate. The plates were incubated at $27^{\circ} \mathrm{C}$ for 5 days and colonies counted, mean values calculated and colony forming unit per gram also calculated (Agamuthu et al., 2013).

\section{Tentative identification of isolates}

The colonies grown on nutrient agar and Bushnell Haas mineral salt agar were subcultured on nutrient agar and incubated at $37^{\circ} \mathrm{C}$ for $24 \mathrm{~h}$ until pure isolates were obtained. Pure bacterial isolates from the baseline studies, days 0,14 and 28 were tentatively identified based on their phenotypic and biochemical characteristics as described in Bergey's Manual of Determinative Bacteriology (Holt et al., 1994).

\section{Statistical analyses}

One-way analysis of variance (ANOVA) was used to analyze data from bacterial counts, PAH degradation efficiency was gotten using IBM SPSS Version 21 to determine the level of significance at $\mathrm{p}<0.05$ and half-life to determine time it can take to degrade half the quantity of pollutant present in the soil sample. Excel inbuilt statistical package was used for graphical illustration of data.

Degradation efficiency $=\mathrm{PAH}$ initial concentration - PAH final concentration/ PAH initial concentration X 100

Half-life $=\operatorname{In} 2 / \mathrm{K}$

Where $\mathrm{K}$ is the degradation gradient for each treatment setup

\section{Results and Discussion}

The results of the baseline study of the soil sample showed that the concentration of polycyclic aromatic hydrocarbon was $13,453.4 \mathrm{mg} / \mathrm{kg}$ which was higher than that of the Department of Petroleum Resources (DPR) intervention limit of $40 \mathrm{mg} / \mathrm{kg}$ (EGASPIN, 2018) hence, there was need for bioremediation. Results of physiochemical analyses $(\mathrm{pH}$, total organic carbon, nitrate, phosphate, potassium, and polycyclic aromatic hydrocarbon) and microbiological analysis (THB and HUB counts) are shown in Table 2. The microbiological results $(8.7 \mathrm{x}$ $10^{5} \mathrm{Cfu} / \mathrm{g}$ for $\mathrm{THB}$ and $4.1 \times 10^{5} \mathrm{Cfu} / \mathrm{g}$ for HUB) showed that there were active indigenous organisms that can bring about the biodegradation of $\mathrm{PAH}$ process when enhanced. It was also observed that the $\mathrm{pH}$ ranged from $5.96 \pm 0.06$ to $6.33 \pm 0.01$, which were slightly acidic, and $\mathrm{pH}$ range of $6-7$ has been reported to be optimum for bioremediation. The bacterial counts for the amendments as observed in Table 2 showed 
that, the total culturable heterotrophic bacteria present in the amendments are appreciable including; $1.2 \times 10^{6} \mathrm{cfu} / \mathrm{g}, 1.5 \times 10^{6} \mathrm{cfu} / \mathrm{g}$ and $1.0 \times 10^{6} \mathrm{cfu} / \mathrm{g}$ for fishpond effluent, spent mushroom substrate and compost soil respectively.

The various bacterial genera identified from the amendments and soil is shown in Table 3. Form the result, fishpond effluent had 6 bacterial genera identified as: Pseudomonas, Bacillus, Serratia, Vibrio, Klebsiella and Micrococcus. For the spent mushroom 5 bacterial genera: Pseudomonas, Bacillus, Enterobacter, Micrococcus and Staphylococcus. For compost soil 8 bacterial genera were identified which includes; Pseudomonas, Bacillus, Micrococcus, Escherichia, Klebsiella, Serratia, Enterobacter and Arthrobacter. While 6 bacterial genera were identified for the polluted soil which includes; Pseudomonas, Bacillus, Alcaligenes, Chromobacterium, and Arthrobacter.

Results of the THB and HUB counts were used to monitor the bioremediation rate for a period of 28 days under laboratory conditions. Presence of bacterial activities were confirmed by quantification and pure isolates of the total heterotrophic bacterial and hydrocarbon utilizing bacterial counts in all setups [1 (control), setup 2 (PS + FPE), setup $3(\mathrm{PS}+\mathrm{SMS})$ and setup $4(\mathrm{PS}+\mathrm{CS})]$ over the 28 days bioremediation period. Figures 1 and 2 shows the THB and HUB counts over the monitoring period. The total heterotrophic bacterial counts ranged from $1.3 \times 10^{5} \mathrm{cfu} / \mathrm{g}$ to $2.3 \times 10^{6} \mathrm{cfu} / \mathrm{g}$ across the treatment setups. The highest total heterotrophic bacterial counts of $2.3 \times 10^{6} \mathrm{cfu} / \mathrm{g}$ was observed in setup 3 at day 14 and the least count was observed from control at day 28 which had $1.3 \mathrm{x}$ $10^{5} \mathrm{cfu} / \mathrm{g}$. Hydrocarbon utilizing bacterial counts ranged from $1.0 \times 10^{5} \mathrm{cfu} / \mathrm{g}$ to $1.32 \times 10^{6} \mathrm{cfu} / \mathrm{g}$ across the microcosm, the highest count was observed in setup 3 (1.32 $\left.\mathrm{x} 10^{6} \mathrm{cfu} / \mathrm{g}\right)$ at day 14 and the least from control $\left(1.0 \times 10^{5} \mathrm{cfu} / \mathrm{g}\right)$ at day 28 . The bacterial isolates identified include: Bacillus $\mathrm{sp}$, Staphylococcus sp Klebsiella sp, Micrococcus sp, Pseudomonas sp, Serratia $\mathrm{sp}$, and Chromobacterium sp; Hydrocarbon utilizing bacterial genera were: Klebsiella sp, Pseudomonas sp, Chromobacterium sp, Enterobacter sp, Bacillus sp, Alcaligenes sp, Flavobacterium sp, Arthrobacter sp and Micrococcus sp.

\section{Degradation of PAHs across the Microcosm over the Monitoring days}

Polluted soil samples from each treatment setups (control, FPE, SMS, CS) were subjected to Gas Chromatograph - Flame Ionization Detector (GC-FID) instrument to monitor the level of PAH degradation in all the microcosm over the 28 days period.

The level of PAH concentration in the polluted soil in each microcosm reduced drastically over time (days) as seen in figure 3 showing the biodegradation potential and half-life for PAH. The total PAH (made up of naphthalene, acenaphthylene, acenaphthene, fluorene, phenanthrene, anthracene, fluoranthene, pyrene, benzo(a)anthracene, chrysene, benzo(b)fluoranthene, benzo(k) fluoranthene, benzo(a)pyrene, indeno(1,2,3cd) pyrene, dibenzo(a,h)anthracene, benzo $(\mathrm{g}, \mathrm{h}, \mathrm{i})$ perylene) at day 0 was $12,862.1 \mathrm{mg} / \mathrm{kg}$. It was observed that the values reduced significantly across all microcosms at day 28 , with the amendments having highest reduction while the control (natural attenuation) had the least reduction. At day 28 the values obtained were; control had $12,090.6 \mathrm{mg} / \mathrm{kg}$, CS had 2,056.2mg/kg, FPE had $1,282.8 \mathrm{mg} / \mathrm{kg}$ and SMS had $2,233.1 \mathrm{mg} / \mathrm{kg}$. The percentage total PAHs degradation was calculated using the above equation which gave $6.0 \%$ (control, 
unamended microcosm), $87.4 \%$ (FPE), chromatographic profile of all microcosms $79.2 \% \quad(\mathrm{SMS})$ and $82 \% \quad(\mathrm{CS})$. The can be seen in Plates 1 to 5.

Table.1 Experimental Setup for Bioremediation

\begin{tabular}{|l|l|}
\hline Microcosm code & Description \\
\hline Microcosm 1 (NA) & $1000 \mathrm{~g}$ of polluted soil (PS) \\
\hline Microcosm 2 (FPE) & $900 \mathrm{~g}$ of PS $+100 \mathrm{~g}$ of dried fish pond effluent \\
\hline Microcosm 3 (SMS) & $900 \mathrm{~g}$ of PS $+100 \mathrm{~g}$ of dried spent mushroom substrate \\
\hline Microcosm 4 (CS) & $900 \mathrm{~g}$ of PS $+100 \mathrm{~g}$ of dried compost soil \\
\hline
\end{tabular}

Table.2 Baseline characteristics of polluted soil sample, Fishpond waste, spent mushroom substrate and Compost soil

\begin{tabular}{|c|c|c|c|c|c|}
\hline Physiochemical Parameters & Units & Polluted soil & $\begin{array}{l}\text { Fishpond } \\
\text { waste }\end{array}$ & $\begin{array}{l}\text { Spent } \\
\text { mushroom } \\
\text { substrate }\end{array}$ & $\begin{array}{l}\text { Compost } \\
\text { soil }\end{array}$ \\
\hline Texture & - & Smooth & Smooth & Rough & Grainy \\
\hline Colour & - & Dark brown & Greenish & Light brown & Black \\
\hline pH & - & $6.18 \pm 0.01$ & $6.33 \pm 0.01$ & $6.20 \pm 0.07$ & $5.96 \pm 0.06$ \\
\hline Phosphate & $\mathrm{Mg} / \mathrm{kg}$ & $4.49 \pm 0.01$ & $8.3 \pm 0.07$ & $4.10 \pm 0.07$ & $4.34 \pm 0.01$ \\
\hline Nitrate & $\mathrm{Mg} / \mathrm{kg}$ & $31.3 \pm 0.07$ & $37.6 \pm 0.01$ & $34.3 \pm 0.07$ & $34.7 \pm 0.07$ \\
\hline Total organic carbon & $\%$ & $7.58 \pm 0.01$ & $8.15 \pm 0.01$ & $7.93 \pm 0.01$ & $7.86 \pm 0.01$ \\
\hline $\begin{array}{ll}\text { Polycyclic } & \text { aromatic } \\
\text { hydrocarbon } & \end{array}$ & $\mathrm{Mg} / \mathrm{kg}$ & $12862.1 \pm 0.07$ & ND & ND & ND \\
\hline Total heterotrophic bacteria & $\mathrm{Cfu} / \mathrm{g}$ & $8.7 \times 10^{5}$ & $1.2 \times 10^{6}$ & $1.5 \times 10^{6}$ & $1.0 \times 10^{6}$ \\
\hline Hydrocarbon utilizing bacteria & $\mathrm{Cfu} / \mathrm{g}$ & $4.1 \times 10^{5}$ & ND & ND & ND \\
\hline
\end{tabular}

Key: $\mathrm{ND}=$ not determined

Table.3 Bacterial genera identified

\begin{tabular}{|c|c|c|c|}
\hline Polluted Soil & Fish pond Effluent & $\begin{array}{l}\text { Spent Mushroom } \\
\text { substrate }\end{array}$ & Compost soil \\
\hline Pseudomonas & Pseudomonas & Pseudomonas & Pseudomonas \\
\hline Bacillus & Bacillus & Bacillus & Bacillus \\
\hline Alcaligenes & Serratia & Staphylococcus & Klebsiella \\
\hline Chromobacterium & Vibrio & Micrococcus & Micrococcus \\
\hline Arthrobacter & Klebsiella & Enterobacter & Serratia \\
\hline Flavobacterium & $\begin{array}{l}\text { Micrococcus } \\
\text { Shewanella } \\
\text { Myroides }\end{array}$ & & $\begin{array}{l}\text { Enterobacter } \\
\text { Escherichia } \\
\text { Arthrobacter }\end{array}$ \\
\hline
\end{tabular}


Fig.1 Total Heterotrophic bacterial counts over the 28 days monitoring period

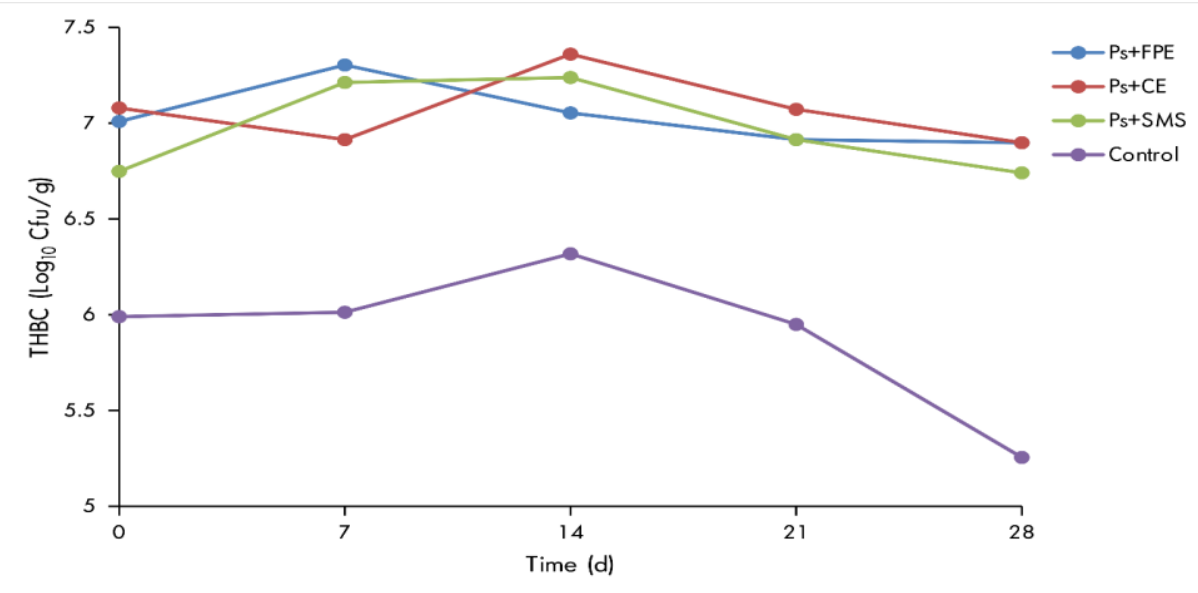

Fig.2 Hydrocarbon utilizing bacterial counts over 28 days monitoring period

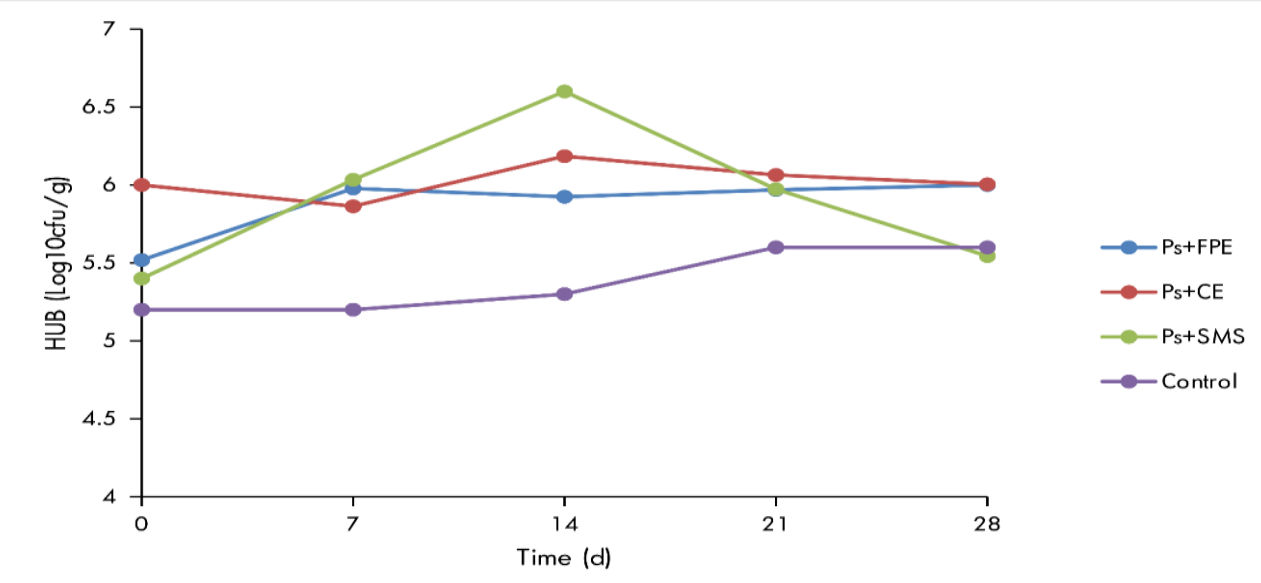

Fig.3 First order kinetic pattern for PAH reduction in all microcosms from day 0 to 28

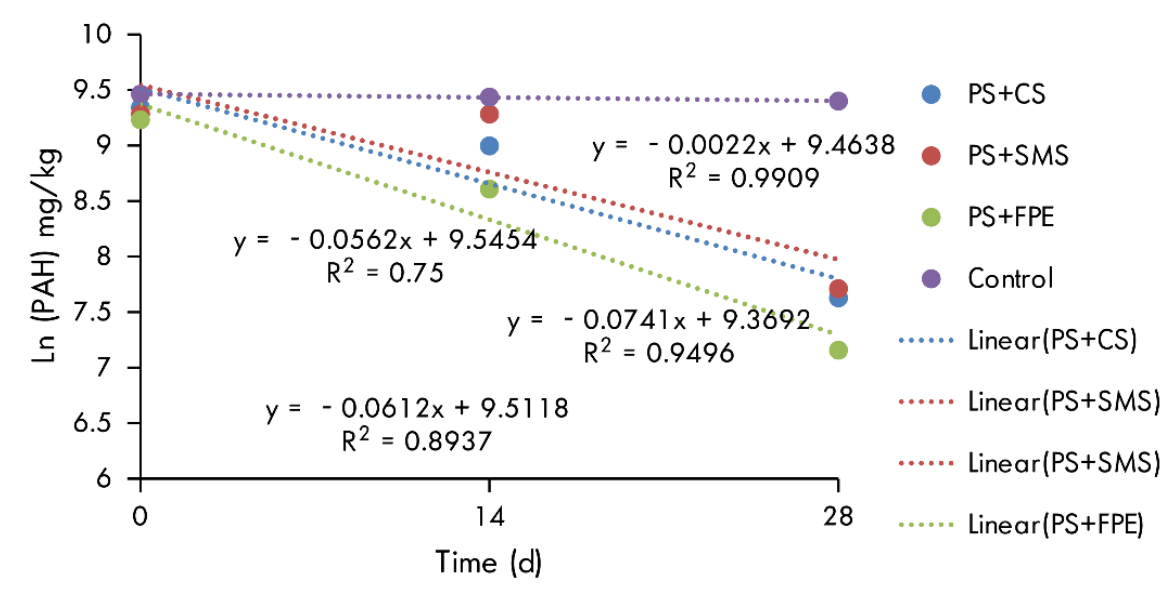


Plate.1 Chromatographic profile for PAH of the soil at Day 0

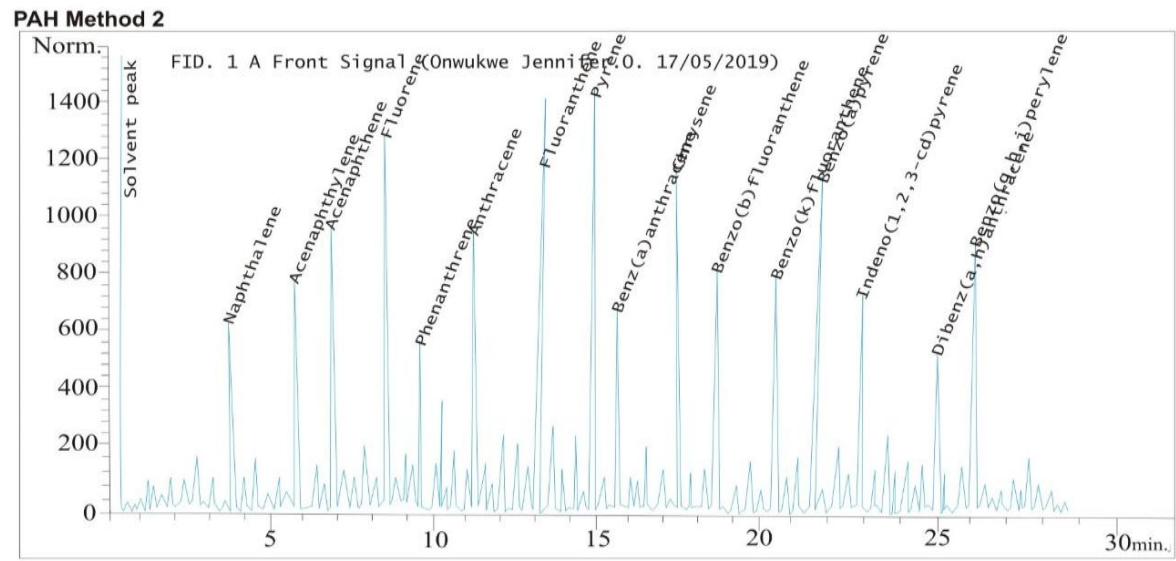

Plate.2 Chromatographic profile for PAH in soil amended with Fish Pond Effluent at Day 28

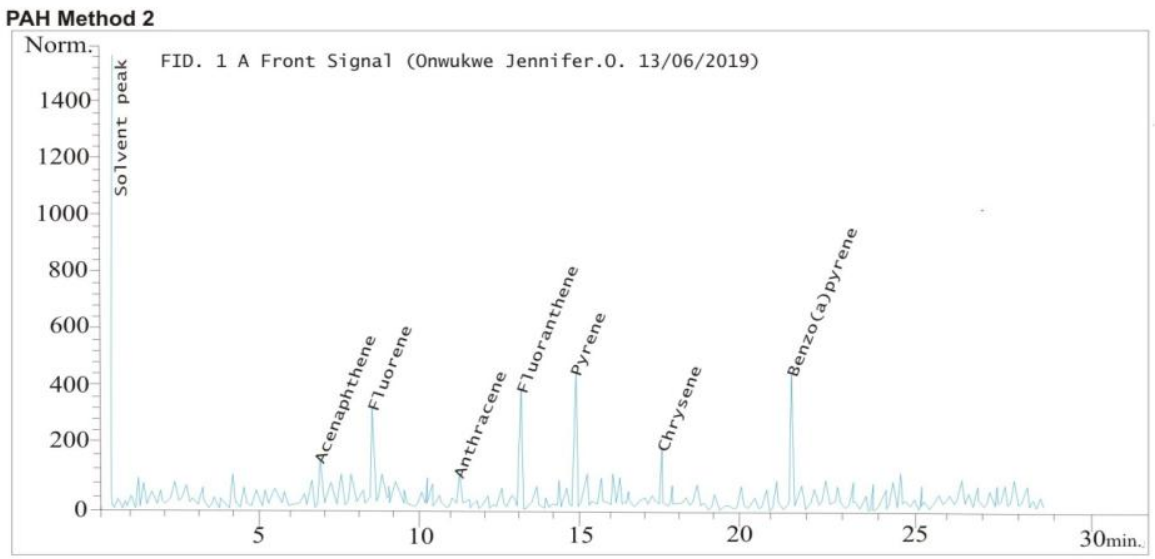

Plate.3 Chromatographic profile for PAH in soil amended with Composit soil at Day 28

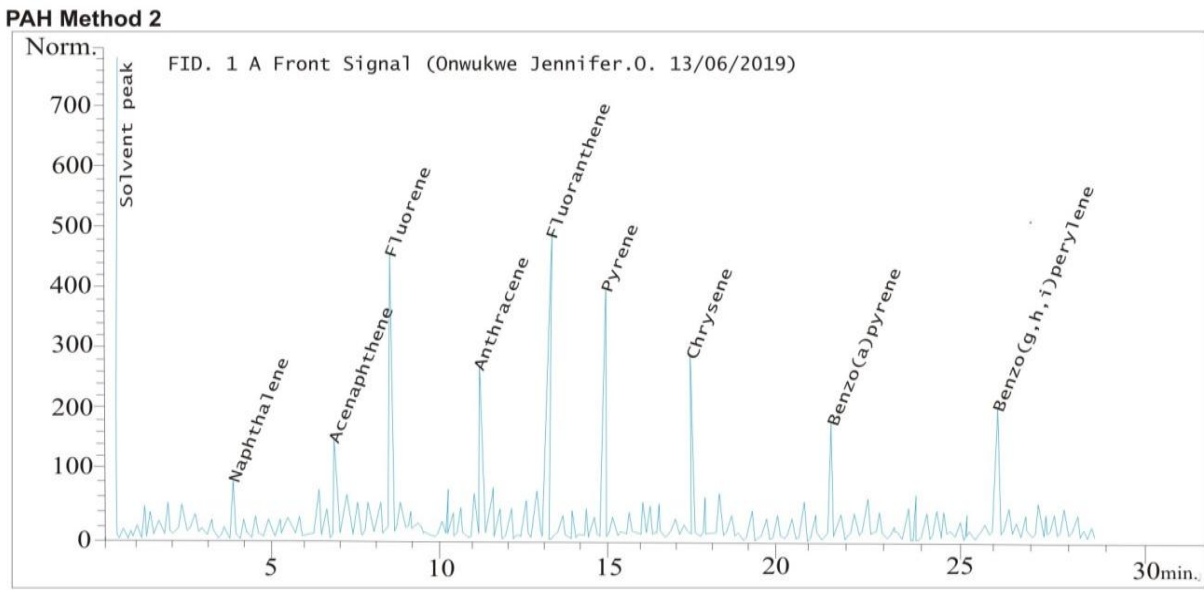


Plate.4 Chromatographic Profile for PAH in Soil Amended with Spent mushroom substrate at Day 28

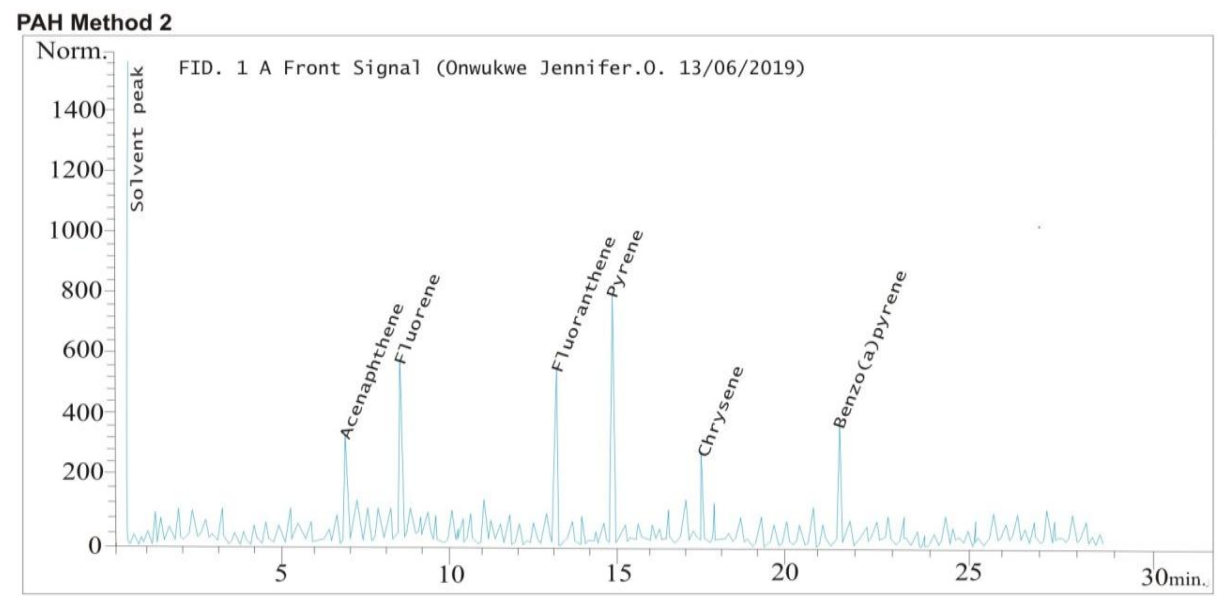

Plate.5 Chromatographic Profile for PAH in Control soil at Day 28

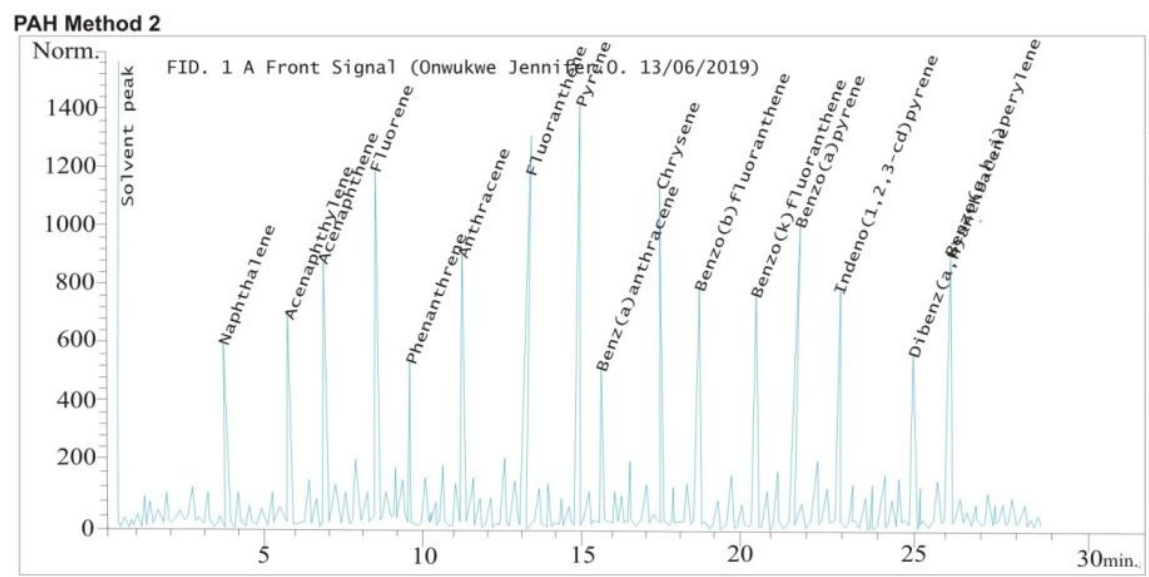

This research was carried out to evaluate the effectiveness of organic amendments in the biodegradation of hydrocarbon polluted soil, resulting from artisanal oil refining activities which are one of the major man-made environmental challenges resulting in the release of crude oil and hydrocarbons including polycyclic aromatic hydrocarbons (PAHs). The results of the baseline study showed that PAH concentrations were far above the DPR intervention limit of greater than $40 \mathrm{mg} / \mathrm{kg}$ (EGASPIN, 2018) so there is need for intervention as PAHs are recalcitrant in nature and chemically toxicogenic. Hence, needs to be eliminated or reduced to harmless level, to resuscitate stressed ecosystem. FPE, SMS and CS were used as sources of amendment for the bioremediation of polluted soil so as to evaluate their individual abilities in degrading high concentrations of PAHs as seen in the results. Also, these organic wastes used in this study are abundant within the area and may constitute a form of nuisance in the environment as a result of improper disposal and management. Therefore, the need of channeling them into a more useful and effective environmental waste management. 
From the results above, the physicochemical characteristics of the polluted soil varied and were adequate to allow the adaptability of bacteria despite the high concentrations of the hydrocarbon pollutant as seen in Table 2 . The polluted soil, is weakly acidic with $\mathrm{pH}$ value of 6.18 and such $\mathrm{pH}$ range is usually optimal for bacterial growth and metabolism (Chikere et al., 2016). Moderately high counts of THB and HUB indicates the presence of active microbial populations in the soil, which may be due to the presence of organic carbon and other environmental conditions that encourages the growth of the microorganisms. This also, shows that even though the pollutant is inhibitory to certain group of bacteria present in the soil, others have the ability to grow and utilize these substances as sources of carbon and energy. The presence of such pollutants, results in selective enrichment of the microorganisms present, but a reduction in the overall diversity of microorganisms and increase in hydrocarbon utilizing microorganisms. The addition of the different organic amendments led to rapid increase in the growth of bacteria and in the degradation of PAHs, reducing the concentration from days 0 to 28. This corresponds with the study carried out by (Abioye et al., 2010) where they observed biostimulation to be more effective in removing low molecular weight PAHs than bioaugumentation.

The bacterial counts in fish pond effluent (FPE) had lower total heterotrophic bacterial counts than the other amendments yet had highest PAH degradation. This could be due to the organic amendment added, which served as a bulking agent, improved aeration, bacterial biomass, moisture holding capacity was also increased which in turn increased the biodegradation rate (Ekwuabu et al., 2016). FPE also had a half-life of 9.3 days with PAH degradative potential of $87.4 \%$ indicating that it would take FPE the shortest number of days to degrade half the amount of PAH in the polluted soil and also has the highest potential of breaking down the hydrocarbons via the increased rate of metabolic activities of the indigenous microbes present in the polluted soil. This proves that fish pond waste/ effluent can serve efficiently as a bioremediating agent. Spent mushroom substrate (SMS) had a rapid increase in hydrocarbon utilizing bacterial counts more than the other setups though with a lower HUB counts and this is in line with another research done by (Udotong et al., 2011) where they observed a rapid increase at the early stage of the bioremediation process which was attributed to their response to high concentrations of petroleum hydrocarbons. But this organic amendment had a PAH degradative potential of $79.2 \%$ and half-life of 12.3 days, which was lower than that of the compost soil (CS). Amendment with compost soil had a $\mathrm{PAH}$ degrading potential of $82 \%$ with a half-life of 11.3 days. This signifies that the break down and utilization of PAH occurred faster in the CS setup than the SMS. The control (natural attenuation) which was not-amended (NA) had the least PAH degradative potential of $6.0 \%$ and a longer half-life of 315.1 days. This indicates that degradation occurred even in the absence of any stimulant showing that the indigenous microbial population present had developed the capability to breakdown these hydrocarbons though it would take many days to degrade half the quantity of hydrocarbons present naturally. Decrease of PAH in control could also be as a result of abiotic factors such as photooxidation, volatilization and weathering activities (Ekwuabu et al., 2016). All counts in the 4 microcosm setups were statistically significant $(p<0.05)$ meaning each treatment could also be effective for degradation of hydrocarbons. Although the control (natural attenuation) will take longest time to remove or reduce the hydrocarbons to an acceptable limit as the indigenous bacteria surviving the 
effects of the pollution adapts and utilizes the hydrocarbons as their main source of carbon based on their metabolic pathways (Eman and Andrew, 2017).

This study indicated the presence of many gram-negative bacteria such as Pseudomonas $\mathrm{sp}, \quad$ Myroides sp, Enterobacter sp, Chromobacterium sp, Klebsiella sp, and Shewanella sp than gram positive bacteria across the microcosm; this is in agreement with other studies where gram negative bacteria were identified as better degraders of hydrocarbons and appears to be very frequent during degradation of crude oil (Stanley et al., 2019). A research carried out by (Eze et al., 2013) showed that various bacterial phylotypes of hydrocarbon degraders act at different stages of PAH bioremediation and in different nutrient amendments; where alphaproteobacteria commences bioremediation then with the addition of biostimulators, betaproteobacteria and gamma proteobacteria takes over (Vinas et al., 2005). The dominance of gram negative bacteria over Gram positive bacteria in the degradation of $\mathrm{PAH}$ is as a result of the complexity of Gramnegative bacteria cell wall which hinders the penetration of certain substances and their entry into the cytoplasm, this is as a result of the presence of porins that helps in the selective uptake of substances by the cell and removal of others which may be harmful (Eman and Andrew, 2017). According to Lazaroaie, (2010), Gram positive bacteria are more sensitive to toxic shock than Gram negative bacteria hence, enabling Gram negative bacteria to dominate oil polluted areas.

In conclusion this research has shown the efficiencies of different organic wastes used as amendments in the bioremediation of PAH polluted soil. At the end of the 28days monitoring period, the results indicated that the organic amendments added had significant biostimulatory effects on the PAH degradation as compared to the unamended (control). However, fishpond waste had the highest potential of breaking down the hydrocarbons via the increased rate of metabolic activities of the bacteria present in the polluted soil, plus the organic waste added to the soil. Therefore, it is recommended that fish pond effluent should be used for bioremediation of polycyclic aromatic hydrocarbon polluted environment. However, there is need for more research into the commercialization of FPE and other agricultural wastes in bioremediation process.

\section{References}

Abioye, P. O., Aziz, A. A. and Agamuthu, P. (2010). Enhanced biodegradation of used engine oil in soil amended with organic wastes. Water Air Soil Pollution. 209: 173-179.

Adams. G. O., Tawari-Fufeyin. P., and Igelenyah, E. (2014). Bioremediation of Spent Oil Contaminated Soils Using Poultry Litter. Research Journal in Engineering and Applied Sciences. 3(2):124-130.

Agamuthu, P., Tan, Y. S. and Fauziah, S. H. (2013). Bioremediation of hydrocarbon contaminated soil using selected organic wastes. Procedia Environmental Sciences. 18: 694-702.

Agency for Toxic Substance \& Disease Registry (ATSDR), Environmental Medicine, Environmental Health Education. (2011). Toxicity of Polycyclic Aromatic Hydrocarbons (PAHs): Health Effects Associated with PAH Exposure. Atlanta, GA. US Department of Health and Human Services.

Avramidis, P., Nikolaou, K. and Bekiari, V. (2015). Total organic carbon and total nitrogen in sediments and soils: a comparison of the wet oxidation- 
titration method with the combustioninfrared method. Agriculture and Agricultural Science Procedia. 4: 425430.

Chikere, C. B, Okoye, A. U. and Okpokwasili, G. C. (2016). Bacterial community dynamics of nutrient enhanced oil-polluted sediment. Nigerian Journal of Microbiology. 30(1)3281-3294.

Chikere, C. B., Fenibo, E. O. and Akaranta, O. (2018). Comparative Effectiveness of Activated Soil in Bioremediation of a Farmland Polluted Soil by Polyaromatic Hydrocarbon in the Niger Delta. Journal of Bioremediation and Biodegradation. 9: 456. (")

Dell'Anno, A., Beolchini, F. and Rocchetti, L. (2012). High bacterial biodiversity increases degradation performance of hydrocarbons during bioremediation of contaminated harbor marine sediments. Environmental Pollution. 167:85-92.

Denedo, M., Thomson, I. and Yonekura, A. (2017). International advocacy NGOs, counter accounting, accountability and engagement. Accounting, Auditing and Accountability Journal, 30(6), 13091343.

Douglas, S. I. (2018). Effect of illegally refined crude oil ("kpo-fire") residue on soil fungi. International Journal of Current Microbiology and Applied Sciences. 7(12):3309-3316

Douglas, S. I. and Cornelius, B. T. (2019). Impacts of artisanal crude oil refining activities on soil microorganisms. Journal of Advances in Biology \& Biotechnology. 2:1-9.

Ekwuabu, C. B., Chikere, C. B. and Akaranta, O. (2016) Effect of Different Nutrient Amendments on Eco-Restoration of a Crude Oil Polluted Soil. Paper Presented at the SPE African Health, Safety, Security, Environment and Social Responsibility Conference and
Exhibition held in Accra Ghana, 4-6 October. SPE-183608-MS Pp $1-17$.

Eman, K. and Andrew, S. B. (2017). Soil bioremediation approaches for petroleum hydrocarbon polluted environments. Microbiology. 3(1):2549.

Environmental Guidelines and Standards for the Petroleum Industry in Nigeria (EGASPIN). (2018). Department of Petroleum Resources (DPR). $3^{\text {rd }}$ Edition, Lagos. Page 183 - 184

Eze, C. N., Ogbonna, J. C., Anyanwu, C. U. and Eze, E. A. (2013). Determination of the relative Abundance and distribution of bacteria and fungi in Bonny light crude oil- contaminated sandy loam soil. Scientific Research and Essays. 8(9): 375-381.

Hamoudi-Belarbi, L., Nouri, L., Bendifallah, L., Hamoudi, S. and Belkacemi, K. (2017). Biostimulation of microbial community by carob (Ceratonia siliqua) to degrade total petroleum hydrocarbon (TPH) in contaminated soil. Springer: Cham, Switzerland. 275276.

Holt, J. G., Krieg, N. R., Sneath, P. H. A., Stanley, J. T. and Williams, S. T. (1994). Bergey's Manual of Determinative Bacteriology. 9th Ed. Williams and Wilkins Company, Baltimore, USA. pp. 71-561.

Hoover, R. (2014). Online database tracks organic nano-particles across the universe. Journal of Science and Technology. 1-3.

Igwo-Ezikpe, M. M., Okpuzor, J., Awodele, O., Nwaokorie, F. O., Foowora, M.A. and Akinbo, M.O. (2010). Prevalence of polycylic aromatic hydrocarbons (PAHs) degrading bacteria in contaminated tropical soil in Lagos, Nigeria: involvement of plasmid in degradation. International Journal of Biological and Chemical Sciences. 4(6): 
2133-2145.

Lazaroaie, M. M. (2010). Multiple responses of Gram- positive and Gram- negative bacteria to mixture of hydrocarbons. Brazilian Journal of Microbiology. 41: 649- 667.

Mills, A. L., Breuil, C. and Colwell, R. R. (1978). Enumeration of petroleumdegrading marine and estuarine microorganisms by the most probable number. Canadian Journal of Microbiology. 24(5): 552-557.

Molina-Barahona, L., Rodrıguez-Vázquez, R., Hernández-Velasco, M., Vega-Jarquin, C., Zapata-Pérez, O., Mendoza-Cantú, A. and Albores, A. (2004). Diesel removal from contaminated soils by biostimulation and supplementation with crop residues. Applied Soil Ecology. 27: 165-175.

Montagnolli, R. N., Matos-Lopes, P. R. and Bidoia, E. D. (2015). Assessing Bacillus subtilis biosurfactant effects on the biodegradation of petroleum products. Environmental Monitoring Assessment. 187(4116):1-17.

Mrozik, A. and Piotrowska-Seget, Z. (2010) Bioaugmentation as a strategy for cleaning up of soils contaminated with aromatic compounds. Microbiological Research. 165: 363-375.

Obenade, M. and Amangabara, G. T. (2014). Perspective: the environmental implications of oil theft and artisanal refining in the Niger Delta region. Asian Review of Environmental and Earth Sciences. 1(2):25-29.

Obi, C.I. (2010), Oil extraction, dispossession, resistance, and conflict in Nigeria's oil-rich Niger Delta. Canadian Journal of Development Studies/Revue canadienned'études du développement, 30(1-2), 219-236.

Okpokwasili, G. C. and Okorie, B. B. (1988). Biodeterioration potentials of microorganisms isolated from car engine lubricating oil. Tribology International. 21(4): 215-220.

Oldare, M., Pell, M. and Svensson, K. (2008). Changes in soil chemical and microbiological properties during 4 years of application of various organic residues. Waste Management 28:12461253.

Rasdy, N. F. A., Sanagi, M. M., Ibrahim, W. A. W. and Naim, A. A. (2012). Determination of polycyclic aromatic hydrocarbons in palm oil mill effluent by soxhlet extraction and gas chromatography-flame ionization detection. Malaysian Journal of Analytical Science. 12: 16-21.

Santos, E. S., Magalh-aes, M. C., Abreu, M. M. and Macı'as, F. (2014). Effects of organic/inorganic amendments on trace elements dispersion by leachates from sulfide-containing tailings of the S-ao Domingos mine, Portugal. Time evaluation. Geoderma. 226-227:188203.

Sayara, T., Saarra, M. and Sanchez, A. (2009). Preliminary screening of cosubstrate for bioremediation of pyrenecontaminated soil through compositing. Journal of Hazardous Materials. 172:1695-1724.

Sharma, S. (2012). Bioremediation: Features, Strategies and applications. Asian Journal of Pharmacy and Life Science. 2(2): 202-213.

Shell Petroleum Development Company (SPDC). (2011). Environmental Performance - Oil Spills.

Singh, D., Chhonkar, P. K. and Pande R. N. (1999). Soil Organic Carbon in "Soil, plant, water Analysis". A method manual, Indian Agricultural Research Institute, Indian Council of Agricultural Research, New Delhi, 1(4)6: 19-19.

Somawanshi, R. B., Tamboli, B. D., Patil, Y. M. and Kadu, P. P. (1994). Twenty-five years of Research on Soil Test Crop 
Response Studies in Maharashtra 1963 - 1993, M.P.K.V. Research \& Public health. 14: 213-233.

Stanley, H. O., Amakiri, M. A. and Okerentugba, P. O. (2015). Characterization of hydrocarbon utilizing bacteria in soil samples collected from various sites in Port Harcourt (Niger Delta, Nigeria). Society for Science and Nature. 4(1): 6-11.

Stanley, H. O., Maeba, S. N., Gbenekanu and Ugboma, C. J. (2019) Crude Oil degradation using spent mushroom compost(SMC) of Pleuritis Florida. Asian journal of advanced research and report. 2(1): $1-9$.

Tomei, M. C. and Daugulis, A. J. (2013). Exsitu bioremediation of contaminated soils: an overview of conventional and innovative technologies. Critical Reviews in Environmental Science and Technology. 43: 2107-2139.

Udotong, I. R., Udotong, J. I., Edu, I. and Kyoung-Woong, K. (2011). Bioconversion of crude oil production sludge into soil conditioner using sawdust as organic amendment.
Geosystem Engineering. 14(2): 51-58. UNEP (United Nations Environment Programme). (2011). Environmental Assessment of Ogoniland. Nairobi: United Nations Environment Programme.

Van- Hamme, J. D., Singh, A. and Ward, O. P. (2003). Recent advances in petroleum microbiology. Microbiology and Molecular Biology Reviews. 67:503-549.

Vinas, M., Sabate, J., Espuny, M. J. and Solanas, A. M. (2005). Bacterial community dynamics and polycyclic aromatic degradation during bioremediation of heavily creosotecontaminated soil. Applied and Environmental Microbiology. 71(11): 7008-7018.

Wang, X., Wang, Q., Wang, S., Li, F. and Guo, G. (2012b). Effect of biostimulation on community level physiological profiles of microorganisms in field- scale biopiles composed of aged oil sludge. Bioresource Technology. 111: 308-315.

\section{How to cite this article:}

Douglas, S. I., C. J. Ugboma and Onwukwe, O. J. 2020. Effects of Three Organic Amendments on Polycyclic Aromatic Hydrocarbon Degradation from Crude Oil Polluted Artisanal Refining Site. Int.J.Curr.Microbiol.App.Sci. 9(12): 488-502. doi: https://doi.org/10.20546/ijcmas.2020.912.059 